\title{
Monotheism and Polytheism
}

\author{
Jan Assmann
}

What is polytheism?

"Monotheism" and "polytheism" are recent words, not older than the I7th century $\mathrm{CE}$, and they have different statuses. Monotheism is a general term for religions that confess to and worship only one god. "One God!" (Heis Theos) or "No other gods!" (first commandment)—-these are the central mottos of monotheism. The religions subsumed under the term polytheism cannot, however, be reduced to a single motto of opposite meaning, such as "Many gods!" or "No exclusion of other gods!" On the contrary, the unity or oneness of the divine is an important topic in Egyptian, Babylonian, Indian, Greek, and other polytheistic traditions. Polytheism is simply a less polemical substitute for what monotheistic traditions formerly called "idolatry" and "paganism" (Hebrew 'ăbôdâ zārâ, Arabic shirk or jabiliya). Whereas monotheism constitutes a self-description of religions subsumed under that term, no such selfdescription exists for polytheistic religions. Monotheism asserts its identity by opposing itself to polytheism, whereas no polytheistic religion ever asserted itself in contradistinction to monotheism, for the simple reason that polytheism is always the older or "primary" and monotheism the newer or "secondary" type of religion. Monotheism is self-description, polytheism is construction of the other. However, although polytheistic religions include a concept of divine unity, these religions undoubtedly do worship a plethora of gods, which justifies applying a word built on the element poly (many) to them. Unity in this case does not mean the exclusive worship of one god, but the structure and coherence of the divine world, which is not just an accumulation of deities, but a structured whole, a pantheon.

\section{Theologia tripertita}

The most cogent theory of polytheism comes from an ancient author. Varro's concept of a "tripartite theology" refers to a general structure that is perfectly 
well applicable not only to the Roman and Greek religions that Varro had in mind, but also to ancient Egyptian and Babylonian religions. These religions know three spheres or dimensions of divine presence and religious experience, which closely correspond to Varro's three theologies, showing that we are dealing here with a rather general structure of polytheism. His theologia naturalis (Greek theologia kosmike, cosmic theology) corresponds to the cosmic dimension of divine manifestation; his theologia civilis (Greek theologia politike, political theology) corresponds to the cultic dimension; and his theologia fabularis (Greek theologia mythikē, mythical or narrative theology) corresponds to the dimension of historia divina, the stories about the gods, their names, epithets, and genealogies (Antiquitates rerum divinarum, frags. 6-10 Cardauns; see also Deities and Demons).

Cosmos. The first dimension of divine presence or manifestation is the cosmos or nature. Polytheistic cosmology views the cosmos as a cooperative process: the deities cooperate in creating and maintaining the world. In Egypt, the sun-god and his daily course across the sky and the underworld beneath the earth form the center of this processual cosmology. In Babylonia and Greece, the gods seem to be less involved in maintaining the cosmic process and freer to intervene in human affairs. There, the aspect of unity and coherence is expressed above all in social and political terms, especially in the model of a royal court. However, the idea of a highest god who rules as a king over the world of gods is common to all polytheisms of the ancient world. Political philosopher Eric Voegelin has coined the term Summo-Deism in order to emphasize the hierarchical structure of polytheism. Typically, the highest god is also the creator (Marduk in Babylonia; Re, later Amun-Re, in Egypt; although in Greece and Rome, according to the best-known cosmologies, neither Zeus/Jupiter nor any other god creates the world; it simply develops out of Chaos on its own).

In Egypt, the highest god combines the aspects of creator, sun, and king. Here, the idea of unity seems most prominent. Before the monotheistic revolution of Akhenaten, however, the fundamental plurality of the divine world in its cosmic manifestation was never questioned. The cosmic process was viewed as an interplay of convergent and divergent powers. Two otherwise antagonistic powers, Horus, the god of royal legitimacy, and Seth, the god of anarchic violence and force, cooperated in defending the sun-god against Apopis, a water-dragon personifying chaos. The order must always be defended against a gravitation toward disorder or entropy. Order is time or movement, and it would come to an immediate standstill if the foe were definitely annihilated once and for all.

In the eyes of the Egyptians, the success of the cosmic process was always at risk. In the same way as the Mesopotamians, the Chinese, and the Romans, Egyptians were constantly occupied in watching the sky and in observing all kinds of natural phenomena with the greatest attention. But whereas in Mesopotamia, China, and Rome this attention was associated with various forms of divination that served to reveal the will of the gods and to foretell the future, in Egypt it was connected with the daily ritual that served to assist the gods in 
maintaining the world, supplementing divine action with ritual action. Thus, the Egyptians observed the regular and the recurrent, whereas cultures that focused on divination observed the exceptional and deviant. In the context of this task and their intellectual preoccupation with it, the Egyptians accumulated an incredible amount of knowledge, a kind of sacred cosmology, whereas the Sumerians and Babylonians, in the context of their preoccupation with divination, accumulated a similar mass of omen literature, which established connections between divine signs and historical or biographical events.

The cosmic dimension provides evidence of the gods through the natural world and its phenomena. Nobody would dream of denying the existence of the divine powers: they are overwhelmingly present in the shape of sun and moon; air, water, fire, and earth; life and death; war and peace; and so on. It is possible to neglect them, to break one of their specific taboos, to miss the correct performance of their rites, but it is impossible to either enter or leave a relationship which is always already established, into which we are born, and which is never the matter of a personal decision.

Cult and political organization. The second dimension consists of the various forms of terrestrial governance in which the gods of a polytheistic pantheon typically participate. The more important deities of a pantheon are "town-gods," and the more important urban centers of a country are a god's cities in the sense that they are strongly associated with the name of a deity whose temple is the chief temple of that town: Marduk and Babylon, Assur and the city Assur, Athena and Athens, Ptah and Memphis, and so on. The pantheon is an assembly of town lords and temple owners, headed, in some cases, by a god whose temple is in the capital and who, for this reason, rules not only his city but the whole country (e.g., Marduk and Babylon) or, in other cases, who has important cults in virtually every city, even if the city worships another divinity as its own (e.g., Zeus is prominent even in Athens). Aspects both of unity and of diversity are prominent in the political and geographical dimensions of godhead as well. The aspect of unity can be represented by the unity of a country and its hierarchical structure of center and periphery (as in Egypt) or by the periodic gathering together of different towns' citizens at centralized cult places such as Olympia (as in Greece), whereas the aspect of diversity finds its expression in the specific identity and profile of the individual towns and regions.

The political dimension of the divine world may also be called cultic, because it is in their function as town lords and ladies that the deities receive cultic worship. The cult is the service that a lord or lady requires and resembles in many respects a royal ceremonial. The feasts are typically celebrated in the form of a procession and have the clear political meaning of territorial ownership and its annual confirmation.

Myth. The third dimension may be called the personal or biographical aspect of the divine world. In a polytheistic religion, a deity cannot be spoken about without reference to other deities. The gods live, act, and display their personalities and characters in interaction, not only or even primarily with 
humans, but with one another, in relation to other gods, in "constellations" that find their expression in myths, genealogies, epithets, names-in short, in everything that can be said about a deity. Divine constellations reflect the fundamental order and elementary structure of human society-husband and wife, brother and sister, mother and son, mother and daughter, father and son, father and daughter, lover and beloved, lord and slave, hero and enemy, and so on. These constellations unfold in stories (myths) of equally fundamental character, founding and modeling the basic structures of human life, institutions, hopes, and experience: love and death, war and peace, identity and transformation, suffering and salvation. The relation between the divine and the human world is anthropomorphic rather than anthropocentric. The natural partner of a deity is another deity, not humanity. The gods of a polytheistic pantheon care above all for themselves, in the second place for their cities and their followers, and only exceptionally for humankind at large. But this relative distance between the divine and the human worlds is compensated for by intense analogy and a relationship of mutual modeling. The structures of the divine world and the stories about the gods reflect the fundamentals of human existence, but they function as models, and not as mirrors. The gods live and die, rule and serve, suffer and enjoy, win and are defeated: they set the norms and forms of human life, which repeats and reflects the timeless models and follows the traces of historia divina.

\section{The "theologization" of history: \\ Anthropomorphism and anthropocentrism}

The tripartite structure of polytheism establishes a rather indirect relation between gods and humans. The sphere of direct encounters and interventions, which plays such an important role in Greek, Roman, and Babylonian mythology, seems to be missing. How shall we account for the widespread belief that illness and misfortune are expressions of divine wrath and that the gods intervene in various forms in human affairs? There seems to be a fourth dimension of divine manifestation and religious experience, which comprises human life and history.

In Egypt, we actually observe the emergence of history as a fourth parameter or dimension of the divine world, starting with the I 8th Dynasty and gaining predominance in the Ramesside age (ca. I300-I IO० BCE). With the emergence of the dimension of history, the relationship between the divine and the human worlds changes from anthropomorphism to anthropocentrism. The gods not only maintain the cosmic process, not only dwell and rule on earth in their temples, and are not only involved in stories that take place in their own sphere among the gods-they also determine the course of human history on earth, the welfare of the state and the people; they do this by sending victories and defeats, health and illness, prosperity and disaster. In Egypt, this "theologization of history" is a new development. In Mesopotamia, however, as in Greece, Rome, and Bronze Age Anatolia, the religious meaning of history seems to 
have been a concept that was in place from the start. Gods supervise the observance of treaties and help to protect the integrity of their sanctuaries and cities. In Mesopotamia we also find the concept of a "personal god," which brings the worlds of gods and humans into closer relationship, while at the same time preserving the principle of plurality and diversity. Each human being has a specific personal god among the lesser gods, who cares for him or her and intercedes on his or her behalf with the greater gods.

Unlike Egypt, where any forms of historiography dealing with longer periods of the past are missing until the Greco-Roman period, Mesopotamia yields many royal inscriptions that narrate the entire extension of a reign and even texts that stretch back over a series of different reigns into the remote past. The Curse on Agade, for example, narrates the history of the rise and fall of the Sargonid Dynasty during the $23 \mathrm{rd}$ and $22 \mathrm{nd}$ centuries BCE. Among other events it relates how King Naram-Sin destroyed the temple of Enlil in Nippur and how Enlil responded to this crime by sending forth the Guteans, who put an end to the Sargonid Empire. Similarly, the fall of the Empire of Ur is traced back, in another text, to certain transgressions committed by King Shulgi. The theological and juridical concept of religious guilt and divine punishment gives meaning to history and coherence to the chain of events and sequence of dynasties. In Egypt, disaster is a manifestation of chaos and blind contingency. In Mesopotamia, however, it is read as the manifestation of the punishing will of a divinity whose anger has been stirred by the king. In yet other cultures, such as Greece, a disaster can be understood as preordained by fate (moira), although fate's decrees are often carried out by the gods. An event such as the Trojan War, therefore, which was viewed as historical by the Greeks, can be given meaning within a larger context of ongoing human culture.

The apex of the theologization of history is reached with biblical, especially Deuteronomistic, historiography (see Van Seters 1983). The idea of forming an alliance with God instead of only appointing certain deities as supervisors of political alliances draws God much more closely into the ups and downs of human affairs than had been the case in Mesopotamia and its neighboring civilizations. There, history was just a field of possible interventions by the gods, favorable or punitive; now it turns into one coherent connection of events stretching from creation until the end of the world, a sequence known as historia sacra in the Judeo-Christian tradition.

However, the idea of divine verdict and intervention was not totally absent even in Egypt. On the contrary, the typically Egyptian idea of a judgment after death appears as the strongest possible manifestation of the principle of divine verdict. But the concept of postmortem human immortality provides a horizon of fulfillment beyond history, whereas in Mesopotamia and Israel, where the concept of human immortality is unknown, every account has to be settled on earth. Here, the horizon of fulfillment is confined to the terrestrial world, but stretched into the future, over generations and dynasties.

In Israel, this fourth dimension of theology tends to prevail over and, in the course of time, to replace the three others. With the rise of monotheism, the 
cosmos ceases to appear as a manifestation of divine presence and comes to be seen merely as the creation, the work of God. The geographical and cultic dimension is reduced, after the reform of King Josiah at the end of the 7 th century, to the temple at Jerusalem and no longer reflects the pluralistic identity of various centers and regions. Historia divina, the stories that are told about the gods and that display their characters and their vicissitudes, is turned into bistoria sacra, the story of the One God and his chosen people. Historia sacra is the successor of both the third or mythic dimension of narrative articulation of divine constellations and the fourth dimension in the traditional Mesopotamian sense of divine intervention in human affairs. YHWH intervenes in human affairs not only occasionally; in entering the covenant with Israel, concern with human affairs becomes YHWH's dominant trait.

Historia sacra is a dimension of divine presence that excludes the principle of plurality. There can be but one lord of history, one divine partner in a story shared by god and humans. There are, however, surprising parallels to such an extremely anthropocentric conception of the divine even in Egypt. A passage in the Instruction for Merikare speaks of the ways that God cares for humans as his cattle or herd, in terms strongly reminiscent of biblical anthropocentrism:

Humans are well cared for, the livestock of god:

he made heaven and earth for their sake, he pushed the greediness of the waters back and created the air so that their nostrils might live. His images are they, having come forth from his body.

For their sake he rises to heaven;

it is for them that he has made plants and animals, birds and fish, so that they might have food.

If he killed his enemies and went against his children, this was only because they thought of rebellion.

For their sake he causes there to be light.

To see them he travels [the heavens].

He established for himself a chapel at their back.

When they weep, he hears.

He created for them a ruler in the egg

and a commander to strengthen the backbone of the weak.

He made for them magic as a weapon

to ward off the blow of fate, watching over them night and day.

He thrashed the cowardly among them, as a man beats his son for the sake of his brother.

God knows every name. 
This is not only an extremely anthropocentric view of creation, it is also a monotheistic view of the divine. The text speaks of God; other gods are not mentioned. This kind of monotheism, however, is not a matter of religion, but of genre and perspective. If one looks at the world in the way that this text does, the principles of plurality and differentiation disappear, and the ultimate unity of the divine appears. This perspective is characteristic of the genre of wisdom literature, a forerunner of moral philosophy that reflects in a very general way on the fundamentals of human existence. Egyptian wisdom literature generally speaks of god instead of specific gods. This is not only a generic term, to be filled in by a specific god as the case may be ( $a$ god instead of the god), but a specific term referring to the sun-god and creator, as in the Instruction of Merikare. In the perspective of moral philosophy, this is the only god that really counts, the one god on which everything else (including the other gods) depends. Such a "monotheism of perspective" is conventionally termed henotheism to distinguish it from monolatry as a monotheism of cult, worship, and commitment, whereas the term monotheism is reserved for a combination of both: the transformation of a henotheistic perspective into a full-fledged religion or vice versa, the transformation of a monolatrous cult (which recognizes the existence of other gods but worships only one) into a religion adopting the henotheistic perspective in which the other gods do not exist at all.

In Egypt, the henotheistic perspective of wisdom literature and the polytheism of cult coexist without any apparent conflict. During the New Kingdom, however, the henotheistic perspective starts to affect certain domains of temple literature as well, especially hymns to Amun-Re, the god of the capital, Thebes, who becomes identified with the sun-god of Heliopolis. An early hymn to this god, dating back perhaps even before the New Kingdom, adopts the anthropocentric and henotheistic perspective of Merikare:

Hail, Re, lord of justice, whose chapel is hidden, lord of the gods,

Khepri in his boat, at whose command the gods emerge,

Atum, creator of human beings, who differentiates them and makes them live, who distinguishes people by the color of their skin, who hears the prayers of those in distress, and is well disposed to those who call on him, who rescues the fearful from the overbearing, who judges between rich and poor, lord of perception, on whose lips is the creative word, it is for his sake that Hapi has come, lord of sweetness, great of love, it is to make people live that he has come.

To be sure, the gods, plural, are mentioned in this text, which is still a far cry from real monotheism and even henotheism. Yet the gods are put on a 
level with humans and every other creature, and the general view is clearly anthropocentric and henotheistic. Akhenaten's monotheistic Amarna revolution is the radical consequence of this shift from mythical anthropomorphism to philosophical anthropocentrism. It realizes the henotheistic perspective in terms of cult and religious institutions, turning the sun- and creator-god into the sole and only one and denying the other gods any worship and even existence. In the aftermath of this revolutionary step, the gods are readmitted into cult and general worldview; the henotheistic perspective, however, still prevails, and the gods tend now to be demoted, especially in hymns to Amun, to "names," "manifestations," "symbols," "limbs," and so on, of the One. This post-Amarna theology is closer to pantheism than to monotheism; however, the tripartite structure of divine presence-the cosmic, cultic, and mythic dimensions-is again fully expressed in the religious life of the country, and the new concept of a fourth dimension, history, does not in any way invalidate the importance of the other three.

\section{What is monotheism?}

\section{Evolutionary monotheism}

The idea of unity is not alien to polytheistic religions. On the contrary, the emphasis on the oneness or uniqueness of God or the ultimate unity of the divine world with its plethora of deities is obvious in Mesopotamian and Egyptian texts and increases over time.

Translating gods. In polytheistic religions, the deities are clearly differentiated and personalized by name, shape, and function. The great achievement of polytheism is the articulation of a common semantic universe. It is this semantic dimension that makes the names translatable - that is, makes it possible for gods from different cultures or parts of a culture to be equated with one another. Tribal religions are ethnocentric. The powers and ancestral spirits worshiped by one tribe are different from those worshiped by another tribe. In contrast, the highly differentiated members of polytheistic pantheons lend themselves easily to cross-cultural translation or "interpretation." Translation functions because the names not only have a reference, but also a meaning, namely, the god's specific character as it is unfolded in cosmological speculation, myths, hymns, rites, and so on. This character makes a deity comparable to other deities with similar traits. The similarity of gods makes their names mutually translatable. But in historical reality, this correlation has to be reversed. The practice of translating the names of the gods created a concept of similarity and produced the idea or conviction that gods are international.

The tradition of translating or interpreting foreign divine names goes back to the innumerable glossaries equating Sumerian and Akkadian words, among which appear lists of divine names in two or even three languages, such as Emesal (women's language, used as a literary dialect), Sumerian, and Akkadian. The most interesting of these sources is the explanatory list Anu sa ameli, 
which contains three columns, the first giving the Sumerian name, the second the Akkadian name, and the third the functional definition of the deity. This explanatory list gives what may be called the meaning of divine names, making explicit the principle that underlies the equation or translation of divine names. In the Kassite period of the Late Bronze Age, the lists are extended to include languages such as Amorite, Hurrian, Elamite, and Kassite in addition to Sumerian and Akkadian. In these cases, the practice of translating divine names was applied to very different cultures and religions. The origin of this practice may be identified in the field of international law. Treaties had to be sealed by solemn oaths, and the gods invoked in these oaths had to be recognized by both parties. The list of these gods conventionally closes the treaty. They necessarily had to be equivalent as to their function and in particular as to their rank. Intercultural theology became a concern of international law.

The growing political and commercial interconnectedness of the ancient world and the practice of cross-cultural translation of everything, including divine names, gradually led to the concept of a common religion. The names, iconographies, and rites-in short, the cultures-differ, but the gods are the same. This concept of religion as the common background of cultural diversity and the principle of cultural translatability eventually led to the late Hellenistic mentality, for which the names of the gods mattered little in view of the overwhelming natural evidence for their existence and presence in the world.

Hyphenating gods. Scholars conventionally refer to an Egyptian phenomenon that might be compared to the Mesopotamian technique of translating gods as syncretism. It involves the collocation of two or three different gods, leading to hyphenated names such as Amun-Re, Amun-Re-Harakhty, PtahSokar-Osiris, Hathor-Tefnut, Min-Horus, Atum-Khepri, Sobek-Re, and so on. As a rule, the first name refers to the cultic/local dimension, the actual temple owner and lord of the town, whereas the second name refers to a translocal, preferably cosmic deity. Thus, Amun is the lord of Thebes, in whom the sungod, Re, becomes manifest. Ptah is the lord of Memphis, Sokar the god of its necropolis, Osiris the god of the underworld and the dead whose Memphite representation is to be seen in Ptah-Sokar. This relationship between deities does not mean equation or fusion; the gods retain their individuality. Re does not merge into Amun or vice versa. The gods enter into a relationship of mutual determination and complementation: Re becomes the cosmic aspect of Amun, Amun the cultic and local aspect of Re; Atum refers to the nocturnal, and Khepri to the diurnal aspect of the sun-god. Hyphenation implies neither identification nor subordination; Amun has no precedence over Re, nor Re over Amun. In the course of time, however, this practice of "hyphenating" gods fosters the idea of a kind of deep structure identity.

A similar practice occurs in Greece, although with very different ramifications. A god worshiped throughout Greece, such as Artemis, may become associated with a local god whose traits are similar (thus in Arcadia we find Artemis Callisto). In these cases, however, an originally independent god-even a 
god who continues to be worshiped independently in some cases-is subordinated to the Panhellenic god both in the sense that the lesser god's altar is smaller than the greater god's and in the sense that myth makes the lesser god a "heroic" companion of the greater god.

"All gods are One." In Mesopotamia, the pantheon is structured by strong hierarchical relations of subordination, and this, in the long run, fosters similar ideas of deep structural identity. The creation epic, the Enuma Elish, ends with a hymn to the chief god, Marduk, calling him by fifty names. The gods who are subordinated to Marduk become his names, aspects of his all-encompassing essence. Another text assembles a group of major deities, identifying them with roles of Marduk:

Ninirta is Marduk of the hoe,

Nergal is Marduk of the attack,

Zababa is Marduk of the hand-to-hand fight,

Enlil is Marduk of lordship and counsel,

Nabium is Marduk of accounting,

Sin is Marduk, the illuminator of the night,

Shamash is Marduk of justice,

Adad is Marduk of rains.

A hymn of Assurbanipal addresses Marduk as carrying the identity of the three highest gods as personal properties: "You hold the Anu-ship, the Enlil-ship, the Ea-ship." The culmination of these tendencies is reached when the whole pantheon comes to be seen as just aspects of one supreme god. "All gods are three," we read in an Egyptian text (Papyrus Leiden I.350), which moreover states that these three gods are just aspects of one god:

All gods are three:

AMUN, RE, and PTAH, whom none equals.

He who hides his name as Amun,

he appears to the face as Re,

his body is PTAH.

We easily discern here the three "dimensions" of polytheistic theology: name, cosmic appearance, and cultic "embodiment" in a statue, dwelling in a temple, ruling a city. These three dimensions, however, are encompassed and transcended by a god who is referred to as only "He." Amun is just a name screening the true and hidden name of this god, of whom another hymn states:

People fall down immediately for fear

if his name is uttered knowingly or unknowingly.

There is no god able to call him by it.

In Egypt, this concept of a Supreme Being comprising in his essence the whole pantheon goes back to the Ramesside period ( $\mathrm{I}_{3}$ th century $\mathrm{BCE}$ ) and seems to 
be a reaction to Akhenaten's monotheistic revolution. It stresses the oneness of god while retaining the multiplicity of the divine. In the last instance, all gods are but One, the immanent manifold manifestation and diversification of a hidden and transcendent unity.

Hypsistos: belief in a Supreme Being. The idea that the various nations worshiped basically the same deities but under different names and in different forms eventually led to the belief in a Supreme Being (the Greek expression is Hypsistos, the Highest One) comprising in its essence not only all the myriads of known and unknown deities, but above all those three or four gods who, in the context of different religions, play the role of the highest god (usually Zeus, Sarapis, Helios, and Iao = YHWH). This superdeity is addressed by appellations such as Hypsistos (Supreme) and the widespread "One-God" predication Heis Theos. Oracles typically proclaim particular gods to be one and the same together with other gods:

One Zeus, one Hades, one Helios, one Dionysus,

One god in all gods.

Pseudo-Justin, Exhortation against the Greeks I 5 = Orphic frag. 239 (Macrobius,

Saturnalia I.I 8.I7 quotes the first verse)

In one of these oracles, Iao, the god of the Jews, is proclaimed to be the god of time (Olam-Aion), appearing as Hades in winter, Zeus in springtime, Helios in summer, and "Habros Iao" in autumn. (Macrobius, Saturnalia I.I 8.20; see Peterson I926: 243-44; Hengel I969: 476-77; and the inscription Hêิs Zeùs Sérapis Iaó [CIL 2 suppl. $5665=$ Dunand 1975 : I70]). These oracles and predications manifest a quest for the sole and supreme divine principle beyond the innumerable multitude of specific deities. This is typical of the "ecumenical age" and seems to correspond to efforts toward political unification (see Peterson 1935, I95 I; Schindler 1978; Momigliano 1987; Dunand 1975; and Fowden 1993). The belief in the Supreme Being (Hypsistos) has a distinctly universalist character:

The sons of Ogyges call me Bacchus, Egyptians think me Osiris, Mysians name me Phanaces, Indians regard me as Dionysus, Roman rites make me Liber, The Arab race thinks me Adoneus, Lucaniacus the Universal God.

Ausonius, Epigrammata $\#_{4} 8$ (trans. White I9 85 )

This tradition of invoking the Highest God by the names given him by the various nations expresses a general conviction in late antiquity about the universality of religious truth and the relativity of religious institutions and denominations and the conventionality of divine names. According to Servius, the Stoics taught that there is only one god, whose names merely differ accord- 
ing to actions and offices. Varro ( $\mathrm{II}_{\mathrm{I}}-27 \mathrm{BCE}$ ), who knew about the Jews from Poseidonius, was unwilling to make any differentiation between Jove and YHWH because he was of the opinion that it mattered little by which name he was called as long as only the same thing was meant ("nihil interesse censens quo nomine nuncupetur, dum eadem res intelligatur"; Antiquitates rerum divinarum, frag. $16^{*}$ Cardauns). Porphyry held the opinion that the names of the gods were purely conventional. Celsus argued that "it makes no difference whether one calls god 'Supreme' [Hypsistos] or Zeus or Adonai or Sabaoth or Ammon such as the Egyptians do or Papaios as the Scythians.” The name does not matter when it is evident what or who is meant.

In his treatise on Isis and Osiris, Plutarch brings this general conviction to the point, stating that no one would "regard the gods as different among different nations nor as barbarian and Greek and as southern and northern. But just as the sun, moon, heaven, earth, and sea are common to all, although they are given various names by the varying nations, so it is with the one reason [ $l_{0-}$ gos] which orders these things and the one providence which has charge of them" (On Isis and Osiris 67.377f-378a). Seneca stressed that this conviction was based on natural evidence: "This All, which you see, which encompasses divine and human, is One, and we are but members of a great body."

\section{Revolutionary monotheism}

Negative or counterreligion. Whereas evolutionary monotheism may be seen as the final stage of polytheism, there is no evolutionary line leading from polytheism to revolutionary monotheism. This form of monotheism manifests itself in the first place as a negative or counterreligion, defining what god is not and how god should not be worshiped. Revolutionary monotheism is based on the distinction between true and false, between one true god and the rest of forbidden, false, or nonexistent gods. The introduction of this distinction into the realm of religion constitutes a radical break. Polytheistic or "primary" religions generally are not concerned with questions of what to believe, but how to act. Not the truth of the beliefs but the correctness of the ritual performances and recitations is what matters: orthopraxy instead of orthodoxy. No primary religion is concerned with the danger of worshiping "false" gods; their concern is, rather, not to neglect any gods requiring worship.

The first to establish a revolutionary monotheism was Akhenaten of Egypt (ca. I360-I340 BCE). Here, the negative energy of monotheism manifested itself not in explicit prohibitions ("No other gods! No images!"), but in practical destruction. The temples were closed, the cults abolished, the images destroyed, the names erased. Akhenaten's monotheism was based on a physical discovery: the sun was found to generate not only light and warmth, but also time. Light and time were held to be sufficient principles to explain the whole phenomenology of existence; the traditional pantheon was simply deemed superfluous. Its abolition was the logical consequence of a new cosmology. Akhenaten's monotheism was a matter not of revelation but of natural evidence. In this respect, it is closer to polytheism and to evolutionary monothe- 
ism than to revolutionary monotheism in its biblical and postbiblical manifestations.

Biblical monotheism is based not on evidence but on revelation. It is not a matter of cognition but of commitment. It requires adherents to make a conscious decision to accept revealed truth and reject deceitful evidence. Natural evidence is debunked as seduction, as luring people away from revealed truth into the traps and pitfalls of the false gods, that is, the world. The distinction between true and false refers, in its ultimate meaning, to the distinction between god and world. Revolutionary monotheism worships an extramundane or transcendent god, whereas the deities of both polytheism and evolutionary monotheism create and animate the world from within and constitute its life. These religions may be termed "cosmotheism," because they worship the world as a divine being. Biblical monotheism is based on an extramundane truth that cannot be seen or otherwise sensually experienced but only believed "with all your heart, with all your soul, and with all your power," and so is revolutionary as well.

The negative or antagonistic energy of revolutionary monotheism finds its expression, not perhaps in (f)actual history but in textual memory, in scenes of violence such as the story of the golden calf (when 3,000 men and women were cruelly executed), Elijah's competition with the priests of Baal (when the priests were massacred), Josiah's reform (when not only the "high places" [bāmôt] were destroyed but also the priests persecuted and killed), and the forced divorce under Ezra of Israelites married to Canaanites (which was a less bloody but equally violent act). This violence is not a matter of history but of semantics. However, there were always situations when textual semantics led to political action.

Canonization. Revealed truth that cannot be reexperienced in any natural way must be codified in order to be transmittable to future generations. Revolutionary monotheism appeals to memory and transmission rather than to observation, attention, divination, and diligent maintenance. In order to transmit its revolutionary message beyond the first generations of founders and followers, it must develop a body of highly normative and canonized scripture. This applies to Judaism, Christianity, and Islam as well as to Zoroastrianism, Buddhism, Jainism, Sikhism, Confucianism, Daoism, and other religions of the East, all of which are based on a canon. The revolutionary break between cosmotheism and monotheism is everywhere dependent on the invention of writing. It is an "advance in intellectuality" as Freud called it, based on a new cultural technology.

The appeal to memory and the prohibition of forgetting usually assume the form of reading, learning, and interpreting. Remembering means a form of reactualization of the normative impulses as they are laid down in the canon. The texts have not only to be learned by heart but they have to be understood and followed. This implies both believing in the truth of what the texts say and the determination to organize the collective culture and the individual lifestyle according to the codified rules, laws, and norms of scripture.

Idolatry, sin, and the construction of paganism. In consequence of its deter- 
mination to distinguish between true and false, revolutionary monotheism constructs the outside world of former and foreign religions as paganism, a concept completely alien to primary religions. The Greeks knew "barbarians" but no "pagans." However, the distinction is primarily applied within the group itself; it addresses the "pagan within" and cuts right through its own community and even through the individual heart, which now becomes the theater of inner conflicts and religious dynamics. The concept of idolatry became psychologized and turned into a new concept of sin. Among the various innovations brought into the world by revolutionary monotheism, the invention of the "inner person" is of particular importance. Religion becomes a matter of the heart and soul: "The sacrifice acceptable to God is a broken spirit; a broken and a contrite heart, O God, thou wilt not despise" (Ps. 5 I.I9 [= 5I.I7 Hebrew]). "And you shall love the LoRD your God with all your heart, and with all your soul, and with all your might" (Deut. 6.5).

The distinction between true and false religion has not only a cognitive, but also a moral meaning. In this early stage of monotheism, the "false gods" are conceived of as fully existent and powerful beings who constitute a constant temptation and lure the human heart into the pitfalls of idolatry. Idolatry is seen not only as an error but also as infidelity and immorality. Without the existence of other gods, the commandment to be faithful to the one god would have little meaning. The gods of polytheistic religions, in their need of social bonds, formed constellations within their own sphere and were not dependent on humanity. The god of the Bible is a "jealous god," having to count on the love and loyalty of his chosen people, which inevitably fails in fulfilling his expectations. Thus, together with counterreligion, the concept of "sin" is born as the awareness of having failed in requiting God's love and of having given in to the temptations of the false gods.

The theologization of justice. Revolutionary monotheism is a religion in which the idea of justice holds the central position. Whereas in polytheistic religions such as in Egypt, the spheres of cult and justice are carefully separated (justice is for humans, and cult is for the gods and the dead), in the Bible they are emphatically connected. God does not want sacrifice, but justice. Justice becomes the most prominent way of fulfilling the will of God. This led to the still widespread conviction that justice and morals were brought into the world only by monotheism and could not be maintained without it. The construction of paganism implies the idea of lawlessness and immorality. This is, of course, a polemical distortion. The gods, above all the sun-gods (Shamash in Mesopotamia, Re in Egypt), watched over the keeping of the laws and acted as judges. In Egypt, moreover, there is the idea of a general judgment of the dead, which constitutes a first step toward a theologization of justice. But it is true that no god other than YHWH or Allah ever acted as legislator. The idea of justice is divine, but the formulation and promulgation of specific laws is the task of the king. In Egypt, the laws were never codified, and Mesopotamia had law books but no law codes. Every new king was free to promulgate his own laws and was not bound to an existing legislation. The Torah was the first attempt at 
creating a real law code not to be superseded by any future legislation. This was a revolutionary step by which the law-and with it religion itself, whose center the law constituted-became independent of any political government. The ideas of divine legislation, and not only codification but also revelation and canonization, are closely connected. The law formed the content of the Sinai revelation, and its codification in the various law codes in Exodus, Leviticus, Numbers, and Deuteronomy formed the core of the evolving canon.

\section{Bibliography}

Dunand, F. "Les syncrétismes dans la religion de l'Égypte gréco-romaine." In Les syncrétismes dans les religions de l'antiquité, ed. F. Dunand and P. Levêque. Études préliminaires aux religions orientales dans l'empire romain 46. Leiden: Brill, I975.

Fowden, Garth. Empire to Commonwealth: Consequences of Monotheism in Late Antiquity. Princeton: Princeton University Press, I993.

Hengel, M. Judentum und Hellenismus: Studien zu ibrer Begegnung unter besonderer Berücksichtigung Palästinas bis zur Mitte des 2. Jh. v. Chr. Tübingen: Mohr, I969.

Momigliano, Arnaldo. "The Disadvantages of Monotheism for a Universal State." In Momigliano, On Pagans, Jews, and Christians. Middletown, Conn.: Wesleyan University Press, I987.

Peterson, E. Heis Theos: Epigraphische, formgeschichtliche und religionsgeschichtliche Untersuchungen. Göttingen: Vandenhoeck \& Ruprecht, I926.

- Monotheismus als politisches Problem. Leipzig: Hegner, 1935. . Theologische Traktate. Munich: Kösel, I95 I.

Porter, Barbara Nevling, ed. One God or Many? Concepts of Divinity in the Ancient World. [Chebeague, Maine:] Casco Bay Assyriological Institute, 2000.

Schindler, Alfred, ed. Monotheismus als politisches Problem: Erik Peterson und die Kritik der politischen Theologie. Studien zur evangelischen Ethik I4. Gütersloh: Gütersloher Verlagshaus, 1978.

Van Seters, J. In Search of History: Historiography in the Ancient World and the Origins of Biblical History. New Haven: Yale University Press, 1983.

White, H. G. E., ed. and trans. Ausonius. 2 vols. Cambridge: Harvard University Press, I985. 